\title{
SPECIFIC DESIGN OF CRITICAL DRIVETRAIN COMPONENT
}

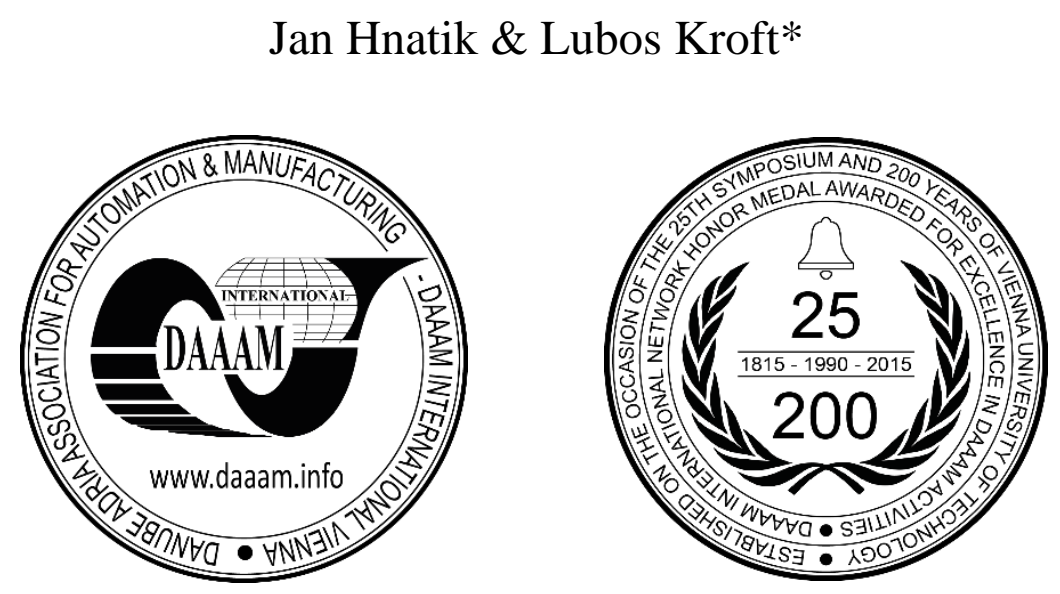

This Publication has to be referred as: Hnatík, J[an] \& Kroft, L[ubos] (2017). Specific Design of Critical Drivetrain Component, Proceedings of the 28th DAAAM International Symposium, pp.0567-0574, B. Katalinic (Ed.), Published by DAAAM International, ISBN 978-3-902734-11-2, ISSN 1726-9679, Vienna, Austria

DOI: $10.2507 / 28$ th.daaam.proceedings.080

\begin{abstract}
The automotive industry can be classified among one of the leading sectors of production engineering. From the perspective of the automotive parts is then the design and their production standard matter. The present contribution focuses on the management area and more specifically on the design and production of steering pinion. This is a common component, but in case of the historic cars, it is issue quite complicated. The aim of the project is just a design new steering pinion so as to be shortened step length and increased its fluidity, thus improving the current state of management over serial. It is therefore an upgrading of the existing type of steering pinion, which is based on the original assembly. On the basis of the input data will be calculated, designed and constructed a new type of steering pinion with steep transfer. This modified pinion steering will be made and implemented to control the assembly of the historic car, where they will test directly in the operation.
\end{abstract}

Keywords: Automotive industry; Historic cars; Steering pinion; Constructed; Test new part

\section{Introduction}

The automotive industry is one of the fastest-growing sectors with a major influence on economy in many countries. The trends of recent years include not only production of brand new cars but also restoration of older vehicles referred to as classic cars. Those active in this field are not only individuals but companies as well, particularly in the recent period.

Their motivations are varied but the restoration activities generally fall into three groups. The first one is restoration to the vehicle's original condition, the second one involves restoration and conversion of the vehicle into a special classic car for racing and the last comprises adaptation to modern trends - tuning.

The latter two types of restoration also involve efforts to improve the properties of the vehicle. In this respect, there is a difference between restoration of old cars and modification of volume-produced modern cars. Parts which can further improve vehicle properties are not generally available for classic cars. 


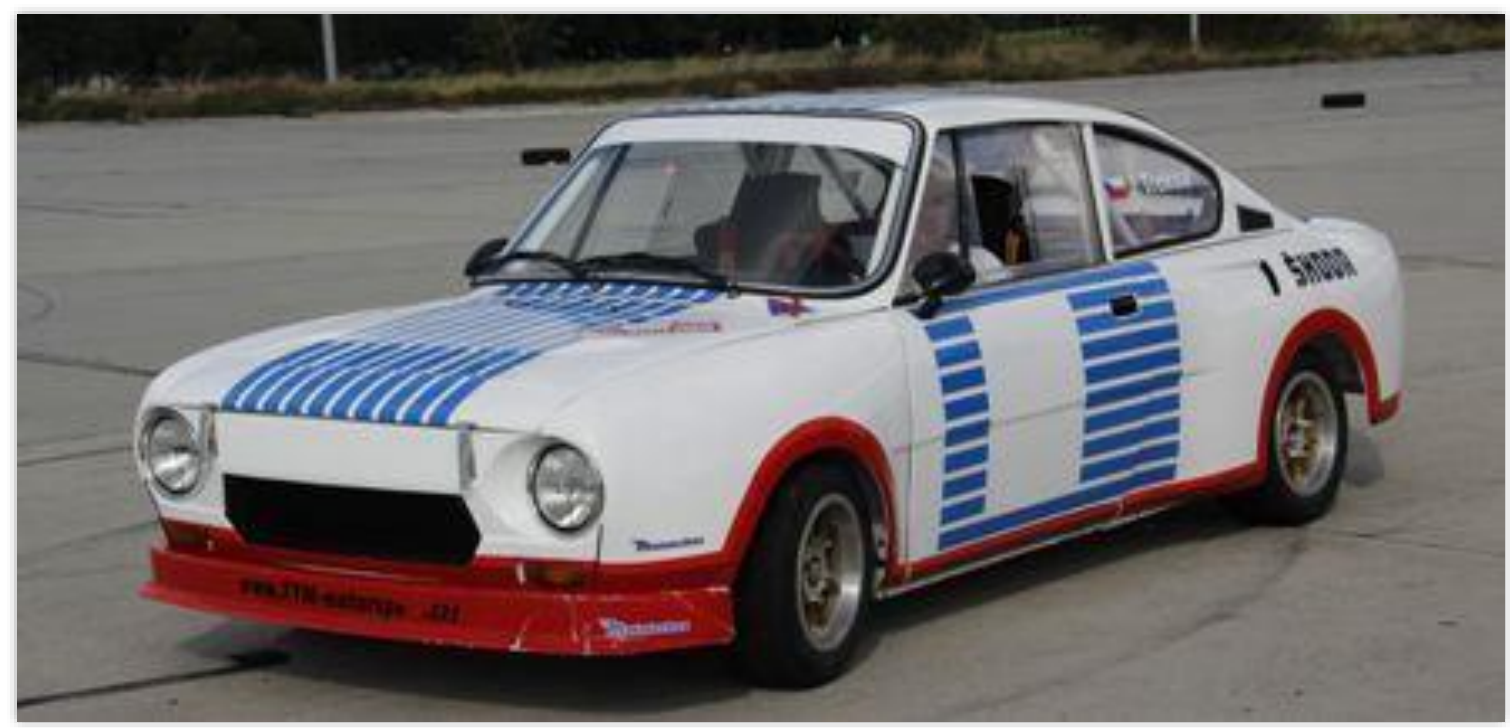

Fig. 1. Škoda 130 RS - Rally Monte Carlo replica [8]

Design, production and testing of a new steering pinion for a Škoda 130 RS, which should have better features than the standard component, was the aim of project that is described in following article. New steering pinion, must be compatible with the original steering system while achieving a shorter steering ratio.

Component pinion with involute teeth is, complicated component from several aspects. An essential consideration is the service life of the pinion and especially the teeth that are the most stressed. For the new type of pinion, it is necessary to choose default material, heat treatment, and finishing operation. The issue of the life service of the gear deals in work with the sources [9] and [10]. Paper with filename "Failure analysis of a pinion" deals with the reason for the rupture of the teeth of the influence of fatigue. Article entitled "Engineering Failure Analysis" on the contrary, addresses the failure of the teeth from the point of view of material and its heat treatment.

For the calculation, design and construction of the new pinion information and formulas from sources [3] and [4] were used. Another important aspect is the machining. The chosen strategy has significant impact on the functional characteristics of the new component. For this reason, the results are quoted in the article "The Influence of Different Types of Copy Milling on the Surface Roughness and Tool Life of End Mills" [2], a very beneficial. Based on them it's possible to design new machining strategy.

\section{Proposal for a new pinion}

As mentioned above, the production of parts for classic vehicles is by far less common than for modern cars. The first parts are not generally available in today's market. Difficulties also arise from the fact that when a part is designed for today's cars, the entire assembly is de-signed at the same time, thanks to which the vehicle properties are improved. By contrast, when a part is being made for a classic vehicle, the resultant assembly comprises original parts and only the part in question is adapted. This is another reason why the opportunities for improvement are considerably limited here.

Therefore, when a new part is to be designed, one has to collect as much information as possible on the original assembly. It becomes yet another challenge because documentation on classic carts is very difficult to find. One often has to turn to reverse engineering to such obtain information.

\subsection{Specifications}

The controllability of a vehicle is of key importance. Unfortunately, a car as a whole is a complex system of interacting elements. Controllability is therefore governed by numerous components, such as wheel suspension, shock absorbers, springs, wheels as such and many others. The steering per se is just one of the many factors that play a role in controllability. However, its design determines the steering ratio. This parameter can be expressed as the number of steering wheel revolutions required for lock-to-lock movement of wheels. Steering ratio is a very important factor for manoeuvring at high speeds and through sharp turns in rallies and track races.

Steering ratio can be reduced by several methods. However, this pinion design is not intended for standard cars, which means that the options are rather limited here. The steering assembly is simple in principle. It consists of the steering housing in which the rotational movement of the steering wheel is transmitted by the steering pinion to the rack. The rack has at its ends tie rods which control the vehicle's axle. The entire system is shown in detail in Fig. 2. [1] 


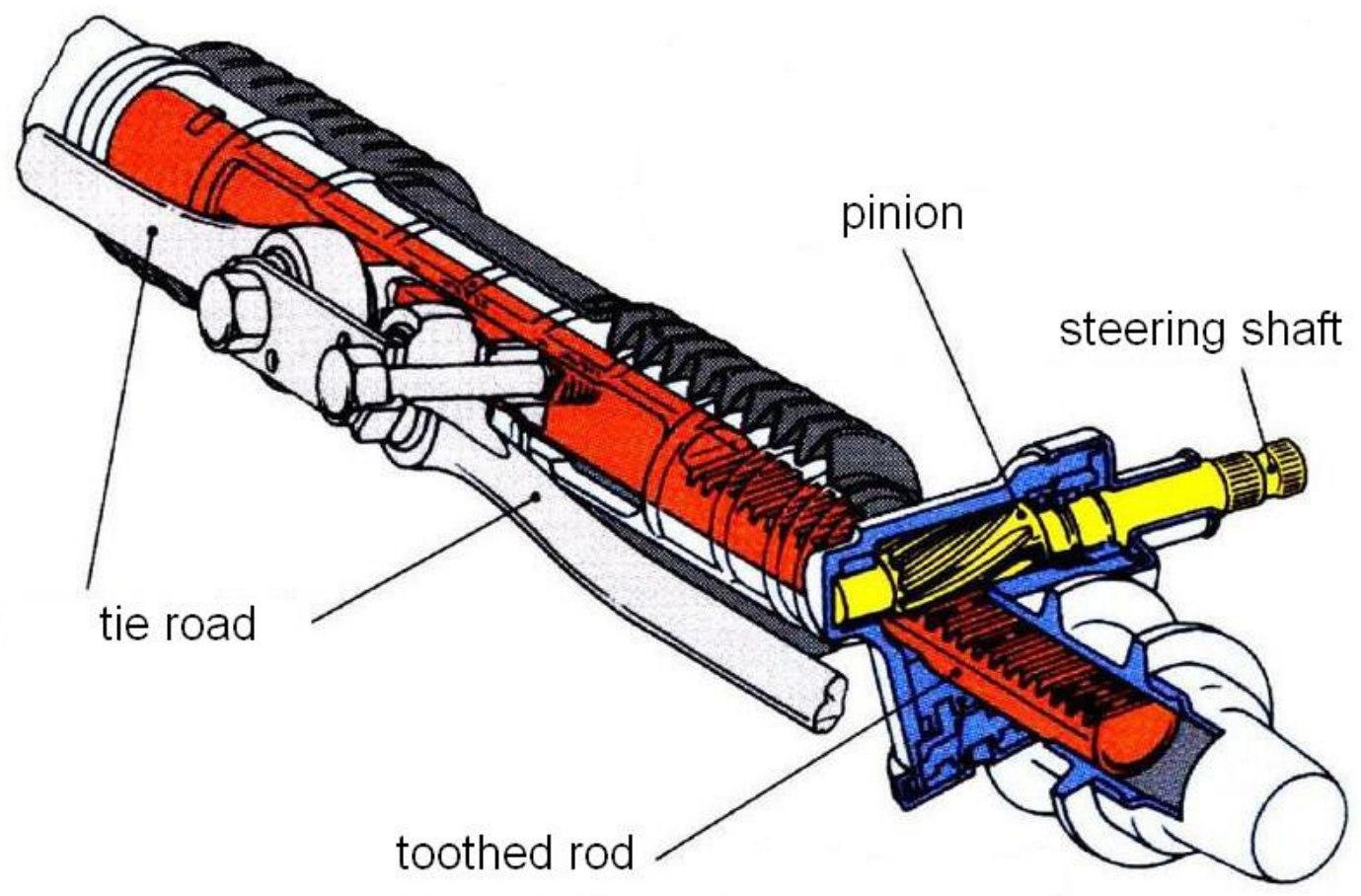

Fig. 2. Rack and pinion steering assembly [1]

The conclusion from the analysis is that the steering pinion represents the only acceptable route for dealing with the issue. This is because if the number of teeth on the steering pinion is increased, the gear ratio increases and the steering ratio becomes lower. For this to be accomplished, the part must be compatible with the original steering system and able to engage correctly with the original rack.

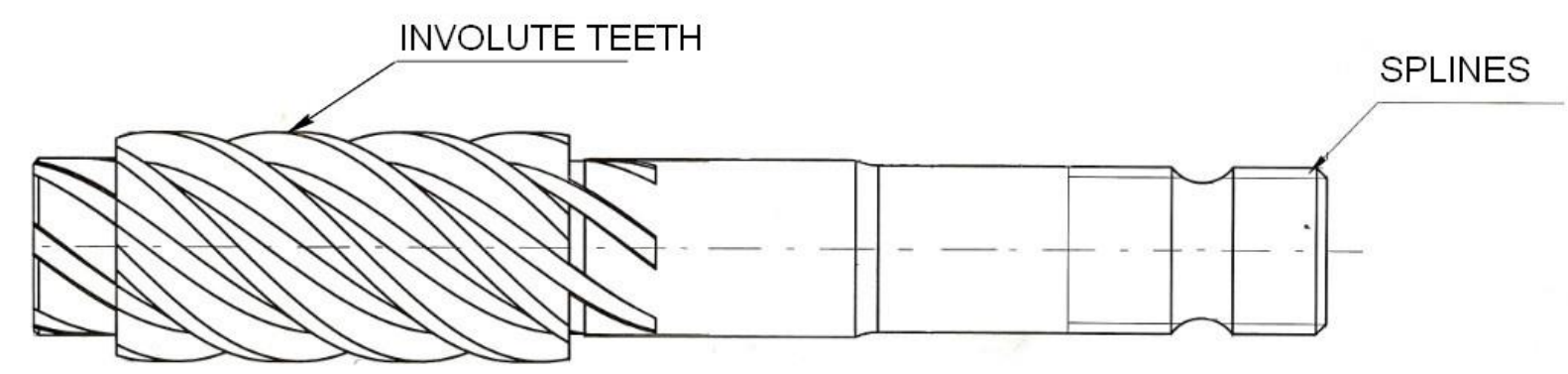

Fig. 3. Steering pinion

The steering pinion (Fig. 3.) is a rotation-symmetric part provided with teeth and splines. Splines are features which provide the connection between the pinion and the steering shaft. The splines are plain rectangular features with a recess at mid-length, at which the pinion is secured to the steering shaft. The teeth are the key functional part of the entire pinion. They are involute teeth in order to provide smooth action of the steering wheel. Besides highly-accurate dimensions and superior finished surface quality, the teeth also need a relatively high hardness. All these aspects must be taken into account in the design process and during manufacture.

\subsection{Investigation of existing pinion}

The purpose of this exercise was to propose, design and manufacture a new steering pin-ion. In order to be able to develop a design for a new steering pinion, it was essential to examine the existing one. This investigation was carried out at the Metrology Laboratory (ML) of the Regional Technological Institute (RTI). As the rack had straight teeth, it was measured using standard methods. The module was measured with a slide calliper. The remaining values were derived from engineering tables. The pinion was measured by means of a 3D measuring machine which offers laser scanning of profiles of parts. 


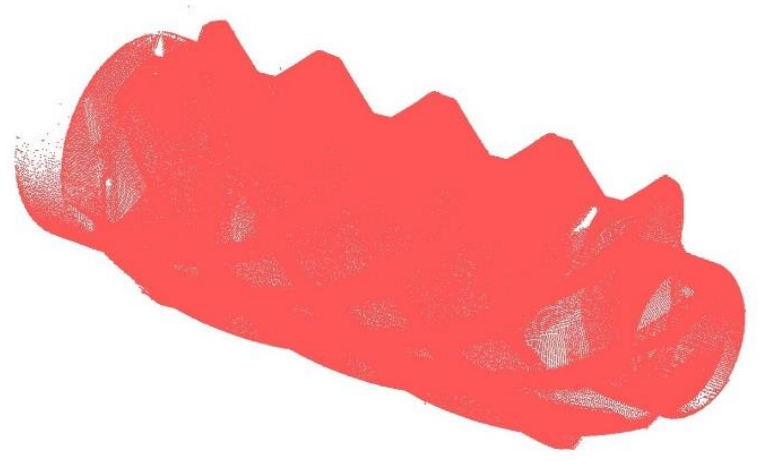

Fig. 4. Pinion model obtained by scanning

Although the new pinion would differ substantially from the existing one, the data that characterize the existing assembly were still important. It was necessary to determine the width of space, the helix angle and many other parameters which would be difficult to obtain by other means.

\subsection{Design of a new pinion}

The new pinion was proposed and designed on the basis of data obtained by examination of the rack and the existing pinion at ML. Since the new pinion is to have one tooth more than the existing one, the tooth profile, the width of space and other parameters had to be modified.

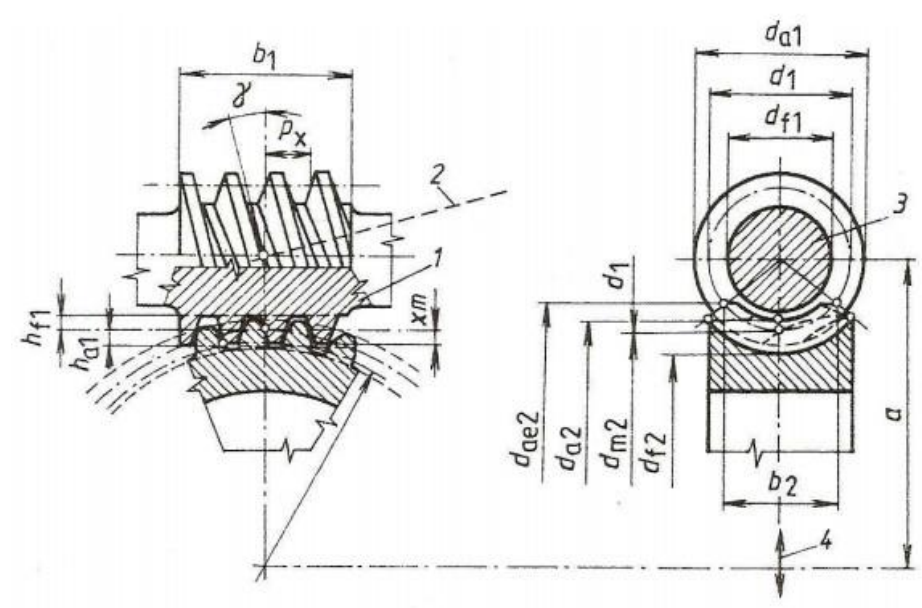

Fig. 5. General drawing of worm gear set and identification of parameters [4]

In the first phase, calculations using basic formulae were completed. As the rack parameters are fixed, only the module value is important:

Verification of the helix angle:

$\tan \gamma=\frac{z_{1}}{q}$

$\mathrm{z} 1$ - number of pinion teeth - to be decided

$\mathrm{q}-$ pinion radius (found by measurement)

$\gamma$ - helix angle

Axial module:

$m_{x}=\frac{m_{n}}{\cos \gamma}$

Axial pitch:

$P_{x}=\pi \times m_{n}$ 
$\mathrm{m}_{\mathrm{n}}-$ normal module (found by measurement)

$\mathrm{m}_{\mathrm{x}}-$ axial module

Pitch circle diameter:

$D_{1}=\frac{z_{1} \times m_{x}}{\tan \gamma}$

$\mathrm{D}_{1}$ - pinion pitch circle



Fig. 6. Profile of tooth

Based on calculated and tabulated values, a new pinion with involute teeth was designed. Unfortunately, the correction of the existing gear was impossible to identify by measurement. Yet, even if this value had been available, the conversion for a pinion with a different number of teeth would have been complicated. Consequently, the solution was to actually manufacture and test the pinion. Fig. 7. shows the final solution which was tested in practice. [5] [6]

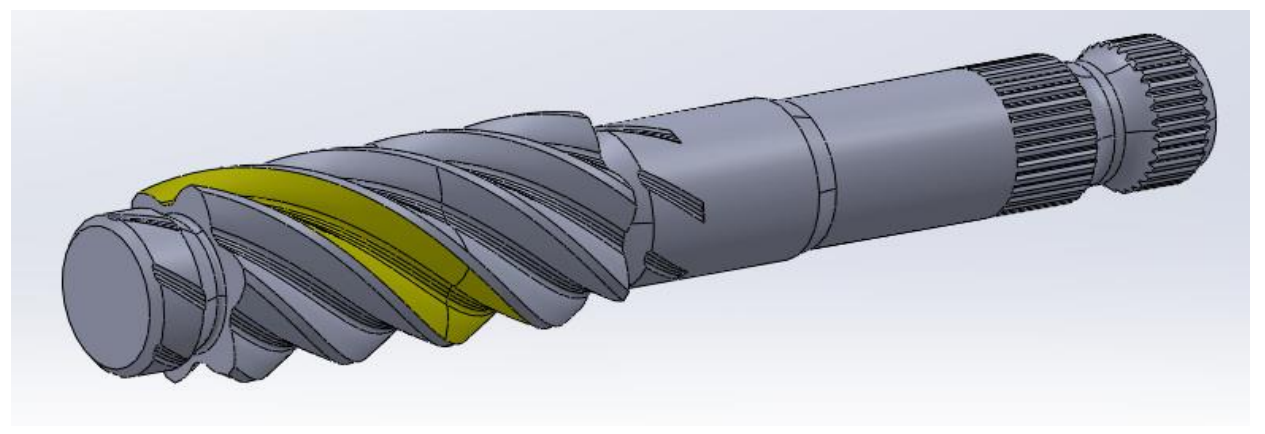

Fig. 7. New steering pinion

\subsection{Selection of pinion material}

As mentioned above, the proper function of the steering system depends not only on dimensional accuracy and good surface finish but also on certain material properties. The reason is that this part is intended not just for ordinary use but also for heavy-duty service in racing cars where loads, both static and dynamic, are significant.

As with any functional component of the transmission system, the part's surface must exhibit sufficient hardness. The value which is appropriate for a steering pinion is $58 \pm 2 \mathrm{HRC}$. This will guarantee that the component is not too soft and that the teeth do not suffer denting or seizure. At the same time, this hardness is not excessively high. Otherwise it would threaten to damage the steering rack or the steering shaft.

The prescribed hardness is required only on the surface and immediately below. The core of the pinion and the interior of the teeth should retain sufficient toughness. This is an essential requirement because of dynamic service loads. Had the part been hardened throughout, it could become brittle. Given the intricate shapes of the teeth, this would have compromised notch toughness and lead to teeth failure.

Upon considering these aspects, W. Nr. 16MnCr5, Czech Standard ČSN 414220.1 was selected as the initial material. It is a low-alloy manganese-chrome steel for case hardening. Its chemical composition is listed in Tab.1. When annealed, this material shows good machinability and is suitable for case hardening. By these processes, one can obtain the properties which are required in a steering pinion. 


\begin{tabular}{|c|c|c|c|c|c|c|c|c|}
\hline $\mathrm{C}$ & $\mathrm{Si}(\max )$ & $\mathrm{Mn}$ & $\mathrm{P}(\max )$ & $\mathrm{S}(\max )$ & $\mathrm{Cr}$ & $\mathrm{Mo}$ & $\mathrm{Ni}$ & $\mathrm{Al}$ \\
\hline $0.14-0.19$ & 0.401 .00 & 1.30 & 0.035 & 0.035 & $0.80-1.10$ & - & - & $\begin{array}{c}\text { At controlled austenitic grain } \\
\text { size } 0.015-0.050\end{array}$ \\
\hline
\end{tabular}

Table 1. Chemical composition of $16 \mathrm{MnCr} 5$ steel [7]

\section{Manufacture of prototype pinion}

Ordinary volume production of gears is a highly specialized effort which requires particular machines and tools. It was impossible to use those because the goal of the entire project was to design, manufacture and test a new type of pinion. It was not cost-efficient to make an investment in special tools for prototype production of several pieces.

The production sequence and the operations were identical for all variants. The only difference in the designs concerned the shapes of the teeth.

Since the basic shape of the semi-finished product was rotation-symmetric, the first operation was the turning of a round rod. The Machining Technology Laboratory (MTL) at the RTI houses a multifunctional turning-milling machine from DMG MORI designated as CTX BE-TA 1250 TC 4A. In this machine, turning can be followed by other operations. This offers a major advantage in the reduction of operation times as transfers to other production machines are eliminated. Another advantage lies in that the machine offers automatic transfers and clamping of the work between spindles which benefits the concentricity of the product.

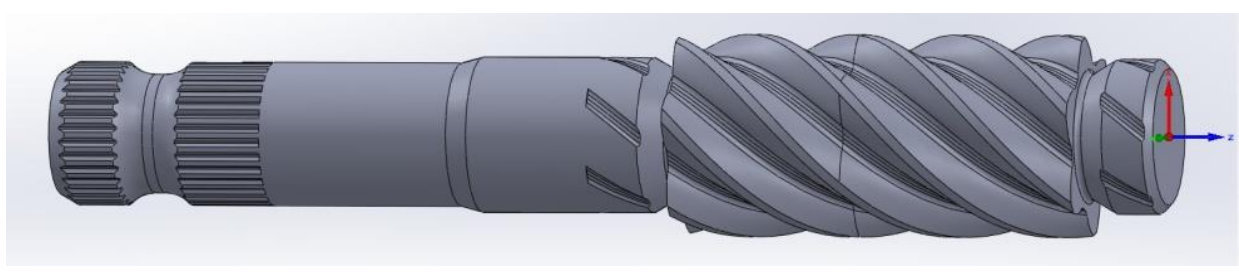

Fig. 8. Design model of the pinion

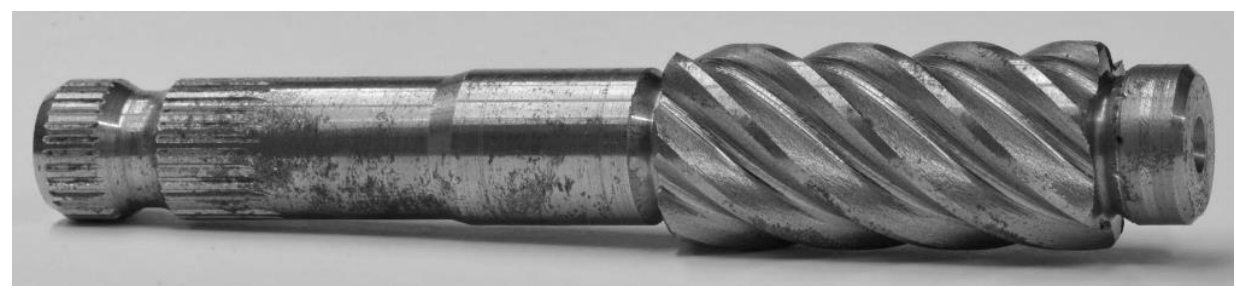

Fig. 9. Semi-finished pinion before finishing operations

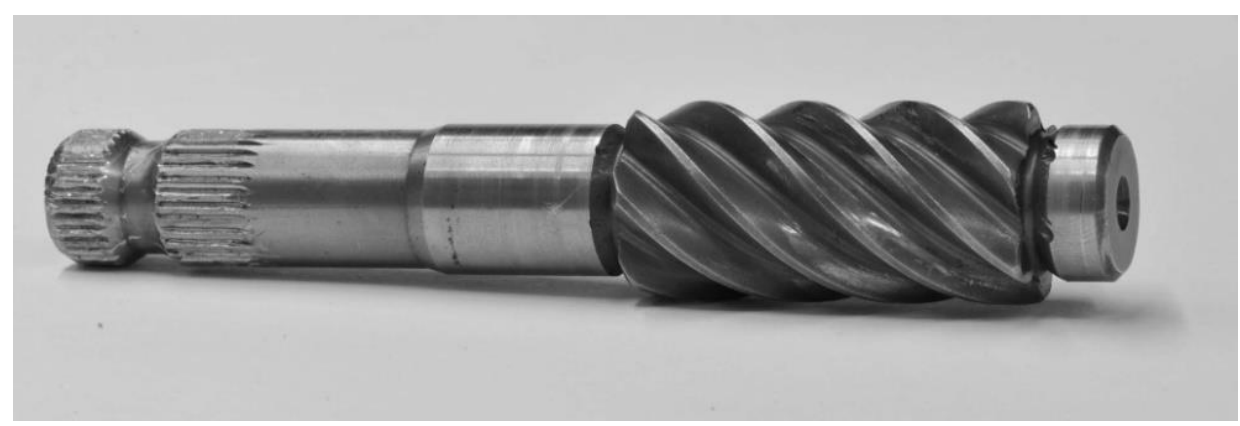

Fig. 10. Finished pinion upon heat treatment and the finishing of all surfaces

The entire basic shape is thus produced with a single clamping operation, including the splines and involute gear teeth. The teeth were rough-cut by cemented carbide (CC) end mills of 2 and $4 \mathrm{~mm}$ diameters, as shown in Fig. 11. A) and Fig. 11. B). Finishing operations were completed with a CC ball mill of $1.8 \mathrm{~mm}$ diameter, as illustrated in Fig. 11. C). In order to achieve the desired quality, a relatively small step over of $0.12 \mathrm{~mm}$ was employed. This provided a sufficient quality of the finished surface, Fig. 11. D. It is not all. The next important parameter (also mentioned in article [2]) direction of the machining has influence influenced of tool life too. In our case strategy of contouring was used instead of copymilling. As shown in the summary, for a constant lifetime is more appropriate to use the strategy from top to down. From this reason was also selected this option. Nevertheless, an additional polishing operation was carried out in OTEC DF 3 machine. 
Polishing was included into the technological process due to the prevention of fatigue cracks. These cracks most often occur in places, notches as indicated in the research reports from the source [10] and [9].

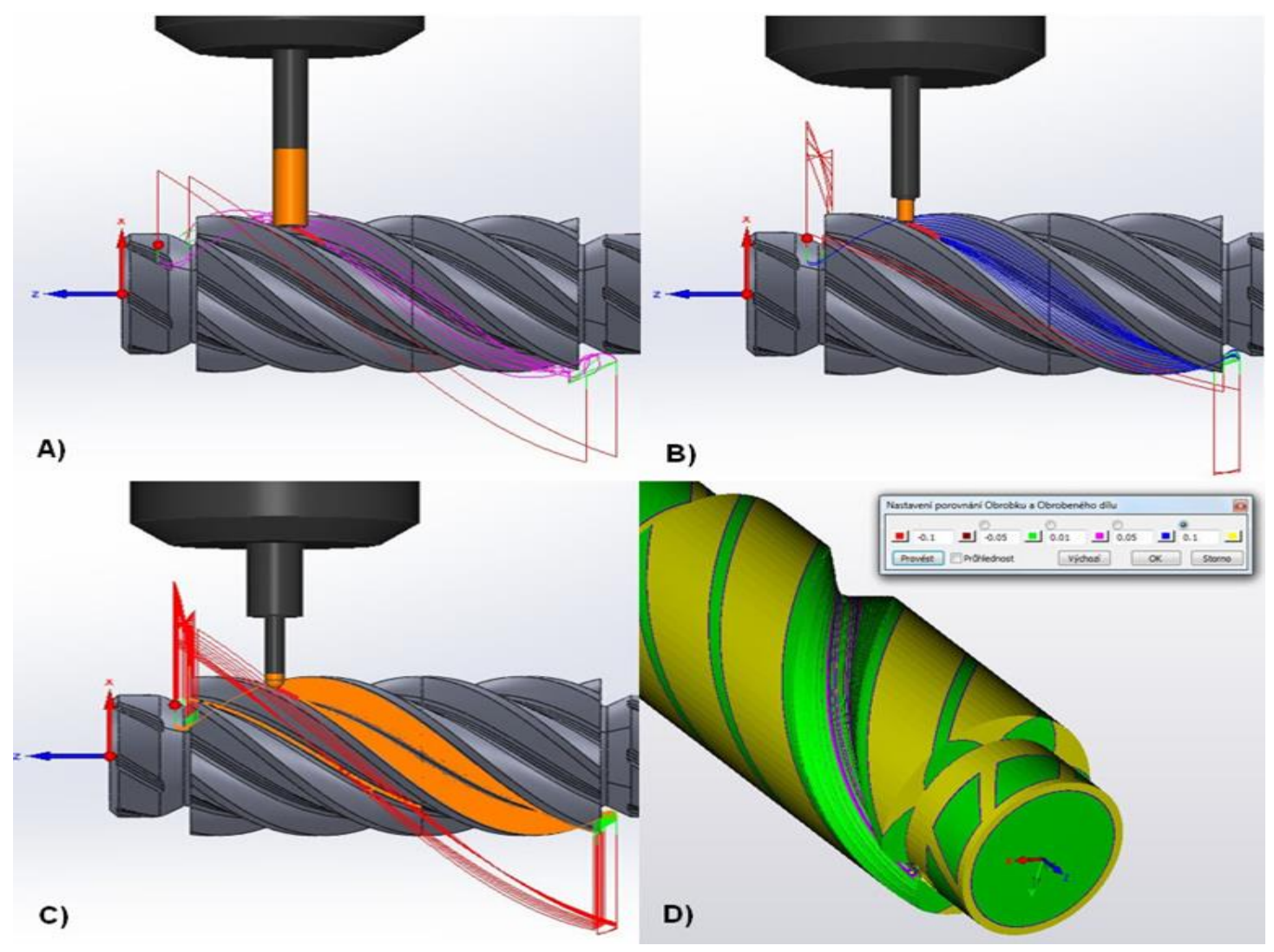

Fig. 11. Production sequence of a pinion tooth: A) roughing, B) pre-finishing, C) finishing, D) CAM analysis of the surface

The production accuracy was verified by the ML. This time, however, a 3D model was al-ready available thanks to which the inspection was completed by contact scanning of surfaces of individual teeth. Deviations of several hundredths of millimetre were detected. Such values are acceptable.

In order to be able to check the functioning of the pinion before subsequent production operations, one of the steering systems was adapted, as shown in Fig. 12., for testing of the pin-ion in the annealed condition. This dummy steering was assembled and areas of contact were checked using engineer's blue in order to select the appropriate variant.

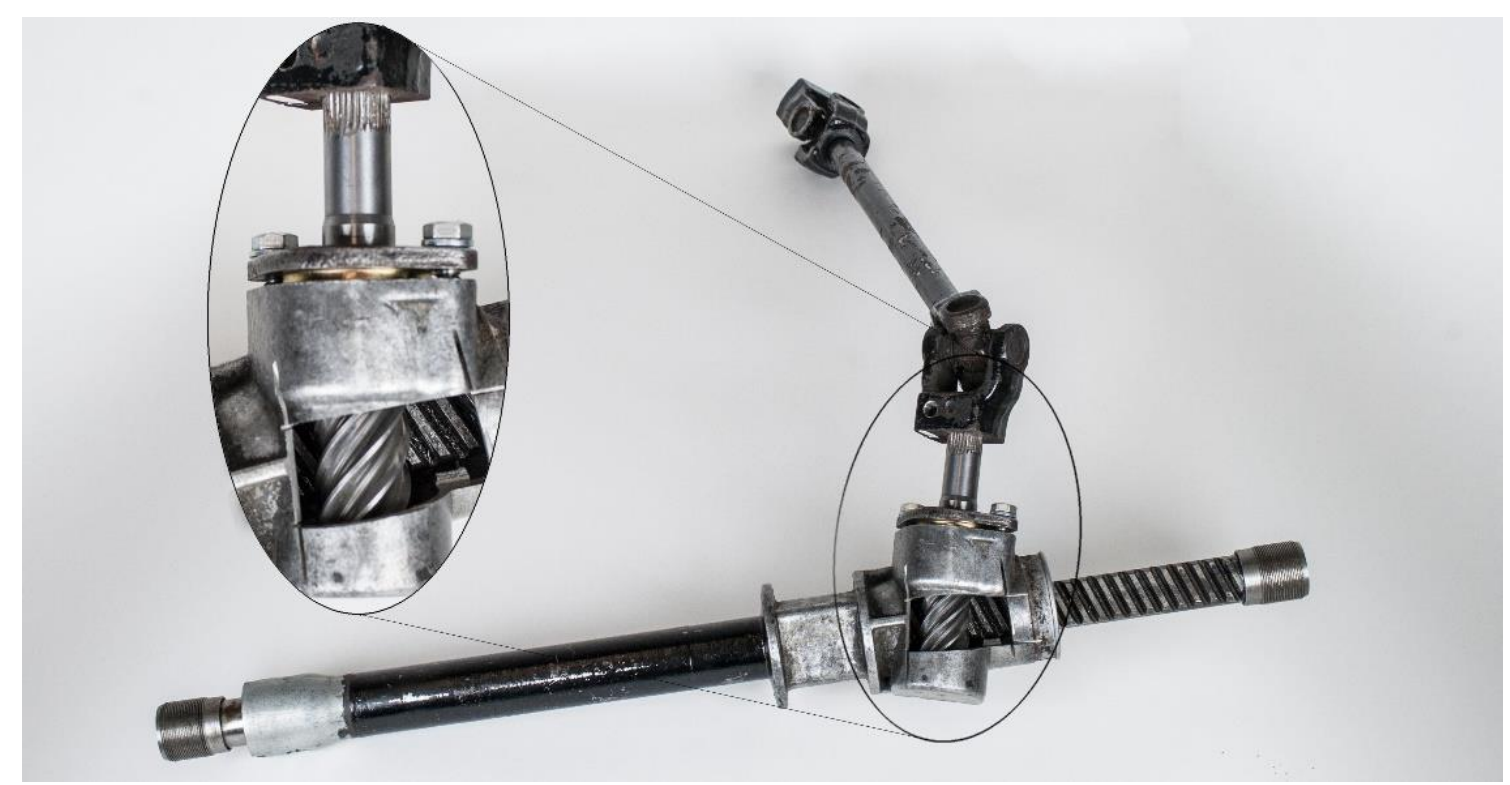

Fig. 12. Dummy steering assembly 
The next production step involved carburizing. This operation was sourced from an authorized external partner. The carburized layer thickness was specified as no less than $0.3 \mathrm{~mm}$. With this appropriate material, it was straightforward to obtain the desired depth and finish the part.

Carburizing in a vacuum furnace produced no scale on the surface and there was no need to regrind the pinion teeth afterwards. This made the production much simpler. The last operation was the grinding of the bearing seats.

The finished pinion was successfully tested in the dummy steering assembly and then installed in an actual car. Testing indicated very good properties of the entire assembly and good engagement of the newly-proposed tooth profile with older and worn racks, which was an un-foreseen extra benefit. Overall, the new pinion proved very successful.

\section{Conclusion}

Components for special classic cars for racing are in short supply. The problem with that led to a decision to upgrade an existing steering pinion type by making a new part which would better meet customer requirements. The project was undertaken jointly with the Regional Technological Institute of the University of West Bohemia.

The objective of the project was to reduce the steering ratio and thus improve controllability of the vehicle. At the start, there was an existing steering assembly. The upgrade was limited to the pinion, whereas the rest of the assembly remained without changes. After the existing pinion had been examined, a new steering pinion for a lower steering ratio was proposed, designed and manufactured to better meet market requirements. This new type of pinion is now being used in both special classic cars for racing and replicas of original vehicles and de-livers a more than satisfactory performance.

Further developments of the pinion were not yet realized, because these testing are so far too short and it is necessary to wait for more data from the real operation and races. If testing goes according to the assumptions of the aim for the future is to apply these outcomes to other types of pinions, or upgrade an already newly designed pinion.

\section{Acknowledgments}

The present contribution has been prepared under project LO1502 'Development of the Regional Technological Institute" under the auspices of the National Sustainability Programme I of the Ministry of Education of the Czech Republic aimed to support research, experimental development and innovation.

\section{References}

[1] Electronic textbook - Ř́zení / Driving. [online]. [accessed on 2017-08-17]. Available from: https://eluc.krolomoucky.cz/verejne/lekce/1491

[2] Vopat, T[omáš]; Peterka, J[ozef]; Simna, V[ladimír] \& Kuruc, M[arcel] 2014. The Influence of Different Types of Copy Milling on the Surface Roughness and Tool Life of End Mills, Proceedings of the 25th DAAAM International Symposium, pp.0108-0116, B. Katalinic (Ed.), Published by DAAAM International, ISSN 1726-9679, Vienna, Austria

[3] Hradilova, P. 2013. Zabezpečovací pohon výrobního zařízení se šnekovou převodovkou a pojistnou spojkou / Security drive of the device with the worm gear and the locking clutch. Tomas Bata University in Zlín, Faculty of Technology.

[4] Taborsky, V. 2009. Návrh pohonu zařízení přes šnekovou převodovku a pojistnou spojku / Design of the drive device through the worm gear and the locking clutch. Tomas Bata University in Zlín, Faculty of Technology.

[5] Bolek, A[lfred] \& K[ochman],. Č́sti strojů / Parts of machines. 5th edition, revised, Praha: SNTL - Publishing house of technical literature, 1990. Technical guide. ISBN 80-030-0426-8.

[6] Leinveber, J[an] \& Vavra P[avel]. Strojnické tabulky: pomocná učebnice pro školy technického zaměření / Mechanical table: an auxiliary textbook for schools technical focus. 4th edition, expanded. Úvaly: Albra, 2008. Technical guide. ISBN 978-80-7361-051-7.

[7] Bolzano - Technical handbook [online]. 2017 [accessed on 2017-08-21]. Available from: http://www.bolzano.cz/assets/files/TP/MOP_\%20Tycova_ocel/EN_10084/MOP_16MnCr5.pdf

[8] Tym-motorsport - stavba závodních automobile / construction of the racing cars [online]. [accessed on 2017-08-22]. Avail-able from:

http://www.tymmotorsport.cz/\#utm_source=firmy.cz\&utm_medium=ppd\&utm_campaign=firmy.cz-2373099

[9] Kosec, G[orazd]; Nagode, A[leš]; Antic I[gor] \& Kosec, B[orut] 2010. Failure of the pinion from the drive of a cement mill. Elsevier- Science direct [online].[cit. 2017-09-06]. Available from: http://www.sciencedirect.com/science/article/pii/S1350630710001858

[10]Das, C.R; Albert, S.K.; Bhaduri, A.K. \& Ray, S.K. 2005. Failure analysis of a pinion. Elsevier- Science direct [online]. [cit. 2017-09-06]. DOI: Engineering Failure Analysis. Available from: http://www.sciencedirect.com/science/article/pii/S1350630704000834 